MARCIN SPYCHAŁA ${ }^{1}$, PIOTR ŁUCYK ${ }^{2}$

${ }^{1}$ Department of Hydraulic and Sanitary Engineering

Poznań University of Life Sciences

${ }^{2}$ Department of Municipal Service in Brzeźno

\title{
EFFECT OF THICKNESS OF TEXTILE FILTER ON ORGANIC COMPOUNDS AND NUTRIENTS REMOVAL EFFICIENCY AT CHANGEABLE WASTEWATER SURFACE LEVEL*
}

\author{
WPŁYW GRUBOŚCI FILTRA WŁÓKNINOWEGO NA SKUTECZNOŚĆ \\ USUWANIA ZWIĄZKÓW ORGANICZNYCH I BIOGENNYCH \\ W WARUNKACH ZMIENNEGO POZIOMU ŚCIEKÓW
}

Summary. The aim of the study was to identify the innovative filters' (textile filters for wastewater treatment) thickness impact on dissolved compounds removal efficiency and related: biomass concentration, hydraulic capacity and hydraulic retention time. The study was conducted on septic tank effluent (STE) which was filtered at changeable wastewater surface between $7 \mathrm{~cm}$ and $20 \mathrm{~cm}$ of height under hydrostatic pressure. The research was performed on filters of thickness: $1.8 \mathrm{~mm}, 3.6 \mathrm{~mm}$ and $7.2 \mathrm{~mm}$. The thinner the filter layer, the lower the total solids content and the higher the hydraulic capacity. The thicker the filter layer, the higher the dissolved compounds removal efficiency. The most efficient in removal were the thickest (eight-layers) filters. The calculated hydraulic retention times were: $0.5,1.1$ and $3.3 \mathrm{~h}$ for two-, four- and eight-layer filters, respectively.

Key words: ammonium nitrogen, dissolved organic compounds, non-woven textile, textile filter for wastewater treatment (TFWT), wastewater treatment

\section{Introduction}

Due to several advantages, in comparison to suspended biomass reactors, e.g. high biomass age, higher resistance to the changeable conditions (Luciano et al., 2012), resulting from high volumetric biomass concentration and ability for higher organic load-

*This work was supported by the National Science Centre under Grant No. N N523 751540. 
Spychała, M., Łucyk, P. (2015). Effect of thickness of textile filter on organic compounds and nutrients removal efficiency at changeable wastewater surface level. Nauka Przyr. Technol., 9, 3, \#44. DOI : 10.17306/J .NPT.2015. 3.44

ing (Nicolella et al., 2000b), considerable research was conducted on attached biomass reactors. There are some disadvantages related to conventional attached biomass reactors, e.g. oxygen access to the liquid phase in some conditions is limited (Nicolella et al., 2000a). A significant part of studies was aimed to investigate alternative materials such as substratum or carriers. Recently, polyurethane foam or other plastic forms of sponge, coconut fibres, granular activated carbon and tire chips have been investigated. Various types of attached biomass systems (bioreactors enabling different oxygen conditions, e.g. aerobic-anoxic reactors, trickling and submerged bed biofilm reactors, hybrid and membrane bioreactors) have been shown to be useful in both organic carbon and nitrogen removal (Gullicks et al., 2011).

There are several types of filters and reactors where textiles are used, e.g. non-woven biological rotating contactors (Liu et al., 2008), but there are also textile filters operating vertically under hydrostatic pressure (gravity driven) without aeration unknown to the authors of this paper (notreported in the references). Therefore the treatment of wastewater (septic tank effluent, STE) under hydrostatic pressure in non-woven textile filters can be considered as a new technology. The term and abbreviation: Textile Filter for Wastewater Treatment (TFWT) has been proposed for this type of filters by the authors of this paper since it was developed by them alongside co-development with Błażejewski (Spychała et al., 2013). These reactors have been already described in relation to performance (Spychała et al., 2013) and biomass-microbial characteristics (Spychała and Starzyk, 2015). It should be noted that filters in the study conducted by Spychała et al. (2013) were made of other types of geotextile (market names: TS 50 and TC/PP 300). The source of wastewater was shown to be different too. Earlier studies on the TFWT (Spychała et al., 2013) showed a relatively high efficiency in organic compounds removal (COD - over $60 \%, \mathrm{BOD}_{5}$ - up to $80 \%$ ) and a potentially significant removal of ammonium nitrogen (30-40\%). On the other hand this technology is new and has not been fully recognised yet and there is still the need to determine the optimal technological conditions (the best efficiency-cost relation). One of the most important technological parameters, related both to treatment efficiency and flow capacity, is the thickness of the filtering layer (Wang et al., 2008).

The first research conducted on TFWT (Spychała et al., 2013) demonstrated the impact of textile type on treatment efficiency - a small but statistically significant difference between ammonium nitrogen removal - 40\% for TS 50 (non-woven continuous fibres) and 35\% for TC/PP 300 (non-woven cut fibres). However, the efficiencies of $\mathrm{COD}$ and $\mathrm{BOD}_{5}$ removal of both types of geotextile were similar. These results showed the validity of geotextile type accordingly to wastewater treatment efficiency. Based on these results non-woven continuous fibres geotextile has been chosen for further studies.

The advantage of attached biomass reactors compared to activated sludge reactors is the possibility to establish high biomass concentration - even over one order of magnitude higher than in activated sludge reactors. In this respect Alimahmoodi et al. (2012) noted the biomass concentration of biofilms $54.200 \mathrm{~g} / \mathrm{m}^{3}$ in the mixed liquor of biomass at the organic loading rate (OLR) of $2.2 \mathrm{~g}$ COD per $1 \mathrm{dm}^{3}$ per day.

Geotextiles of high thickness were investigated by Korkut et al. (2006) in other systems for wastewater treatment - with wastewater overflow of textiles but without filtration. These authors in this context found thick non-woven textiles to be appropriate for denitrifying microorganisms. 
Spychała, M., Łucyk, P. (2015). Effect of thickness of textile filter on organic compounds and nutrients removal efficiency at changeable wastewater surface level. Nauka Przyr. Technol., 9, 3, \#44. DOI : 10.17306/J .NPT.2015. 3.44

The increase in biofilm thickness has an effect not only on biomass concentration in a particular environment but also has an impact on the occurring processes. Dipper zones of biofilm serve as good conditions for denitrification or other processes requiring anaerobic or anoxic conditions. Hibiya et al. (2004) noted that thanks to the isolation of interior space of thick biofilm from oxygen and autotrophs - heterotrophs competition, denitrification can be deemed successful.

Due to the novelty of this type of reactor and lack of information related to the similar technologies and constructions, one can only compare the TFWT with other bioreactors taking into consideration a similarity of some characteristics, e.g. low retention time, high biomass concentration or low dissolved oxygen concentration in the reactor liquid phase.

Biofilm Airlift Suspension reactors (BAS) are promising technological environment and can be seen as an alternative to conventional on-site wastewater treatment plants. BAS enable the growth of biomass at low organic loads and low retention time. However, these reactors operate at a high level of dissolved oxygen (DO). High removal efficiencies ( $90 \%$ for COD and $56 \%$ for $\mathrm{NH}_{4}-\mathrm{N}$ ) can be achieved by BAS (Luciano et al., 2012).

The removal of nitrogen compounds and especially ammonium nitrogen is a very important aspect of on-site wastewater treatment systems due to the high impact of nitrogen on water environment (eutrophisation). Therefore the nitrogen compounds removal in unsophisticated reactors at low costs is preferable. The high nitrogen removal efficiency process is known as anammox. For several years since this process was established, it had been believed to require high nitrogen loading, high temperature and anaerobic conditions (Jin et al., 2012). Recent studies have demonstrated that anammox bacteria can grow at room temperature (Vázquez-Padín et al., 2009), at low nitrogen compounds loading $\left(\mathrm{NH}_{4}-\mathrm{N}: 2.3 \pm 0.38 \mathrm{~g} / \mathrm{m}^{3}, \mathrm{NO}_{3}: 1.47 \pm 1.00 \mathrm{~g} / \mathrm{m}^{3}, \mathrm{NO}_{2}: 2.1 \pm 0.63\right.$ $\mathrm{g} / \mathrm{m}^{3}$, Pathak et al., 2007) and at high dissolved oxygen concentration: 5-8 $\mathrm{g} \mathrm{O}_{2}$ per $1 \mathrm{~m}^{3}$ (Liu et al., 2008). The latter is possible thanks to anoxic conditions in deep layers of biomass consortia (biofilm, biogranules) near the substratum surface. Such conditions can be maintained in anammox and CANON reactors and granular sludge technology.

The removal of the nitrates by denitrification in the biofilm is possible thanks to the stratification of oxygen concentration in the biofilm cross-sectional profile. Two zones can be distinguished: an anoxic deep zone and aerated outer zone. Under such conditions the simultaneous nitrification and denitrification (SND) in a single reactor can be maintained. Such types of bioreactors were investigated as e.g. fixed-film reactors with three zones: aerobic, transition and anoxic (Del Pozo and Diez, 2005), reactors with two zones: aerobic and anoxic zones (Guo et al., 2005; Zhang et al., 2007), a biofilm airlift suspension reactors (Walters et al., 2009) and other types of bioreactors (Li et al., 2010).

On the one hand it can be assumed that higher biomass (assuming stable concentration thicker layer - higher biomass content) causes better efficiency (Chomiak et al., 2014a; Wang et al., 2008). On the other hand there are several other factors, which can correspond in an opposite manner to filtering layer thickness, oxygen accessibility being one example. The precise nature of oxygen access, however, to the internal space of thicker filter layer is unknown.

The aim of the study was to identify the filter thickness impact on dissolved compounds removal efficiency. The additional goal of this research was the investigation of 
Spychała, M., Łucyk, P. (2015). Effect of thickness of textile filter on organic compounds and nutrients removal efficiency at changeable wastewater surface level. Nauka Przyr. Technol., 9, 3, \#44. DOI : 10.17306/J .NPT.2015. 3.44

the thickness impact on hydraulic capacity and biomass concentration. Mean hydraulic retention times were calculated, too.

Due to the possible practical implementation of TFWT as part of an on-site wastewater treatment plant, the main focus of this study turned to organic compounds removal. Another goal was to verify the conditions sufficient for high oxygen-demand aerobic processes, e.g. ammonium nitrogen oxidation. The aim therefore was to verify the hypothesis that in favourable conditions of very low hydraulic capacity and large surface area of filter air side, such processes can arise.

\section{Material and methods}

\section{Preliminary study}

The preliminary study was made on the reactor equipped with one-layer TS 20 geotextile filter, and treating septic tank effluent from one family household located in Grodzisk Wielkopolski city. The time of experiment was 285 days. Average values of main contaminants indicators were: $714 \mathrm{~g} \mathrm{O}_{2}$ per $1 \mathrm{~m}^{3}$ - COD, $333 \mathrm{~g} \mathrm{O}_{2}$ per $1 \mathrm{~m}^{3}$ $\mathrm{BOD}_{5}$ and $137 \mathrm{~g} / \mathrm{m}^{3}$ - TSS. The wastewater level at the start and the end of dosage was $8.0 \mathrm{~cm}$ and $18.0 \mathrm{~cm}$, respectively. The concentration of dissolved oxygen in inflowing and outflowing wastewater was $0.1 \mathrm{~g} / \mathrm{m}^{3}$ and $3.0-4.0 \mathrm{~g} / \mathrm{m}^{3}$, respectively.

\section{Main study}

\section{Research place and time duration}

The research stand-up has been built at a four people household water resource recovery facility in the village of Rybojedzko near Poznań. The study was made on wastewater pretreated in a septic tank of a $3.0 \mathrm{~m}^{3}$ capacity and supplied to three reactors (RI, RII and RIII). In each reactor four non-woven filters were installed (Fig. 1).

The study began with a preliminary experiment on the adjuvant model (from March 2012 to July 2013). This study was dedicated to the recognition of the influence of reactor supply (quasi-continuous supply - very frequent doses at hourly intervals and periodic dosing - every $12 \mathrm{~h}$ ) on filter hydraulic capacity. The main study was carried out in a period of eight months (01.2013-08.2013).

\section{Wastewater inflow characteristics and sample preparation procedure}

The aim of the study was the investigation of textile filters treated as a separate system. The wastewater contained in the reactor (septic tank effluent mixed with the wastewater remaining after the previous doses) was treated as inflowing wastewater (removal efficiency assessment) to avoid the impact of reactor volume outside the filter (additional hydraulic and solids retention time) on removal efficiency. At the beginning of the experiment the test to check the difference between septic tank effluent and wastewater contained in the investigated reactors was made. Small differences were observed - about $3 \%$ for COD $\left(557 \mathrm{~g} / \mathrm{m}^{3}\right.$ and $540 \mathrm{~g} / \mathrm{m}^{3}$ in inflowing wastewater and wastewater inside all three reactors on average, respectively) and below $1 \%$ for ammonium nitrogen $\left(99.7 \mathrm{~g} / \mathrm{m}^{3}\right.$ and $98.7 \mathrm{~g} / \mathrm{m}^{3}$ in inflowing wastewater and wastewater inside 
Spychała, M., Łucyk, P. (2015). Effect of thickness of textile filter on organic compounds and nutrients removal efficiency at changeable wastewater surface level. Nauka Przyr. Technol., 9, 3, \#44. DOI : 10.17306/J .NPT.2015. 3.44

a

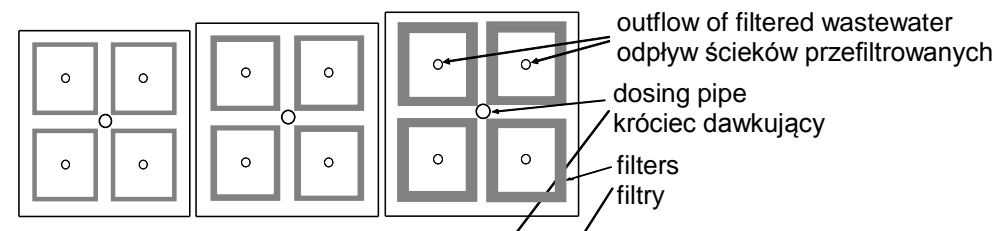

b

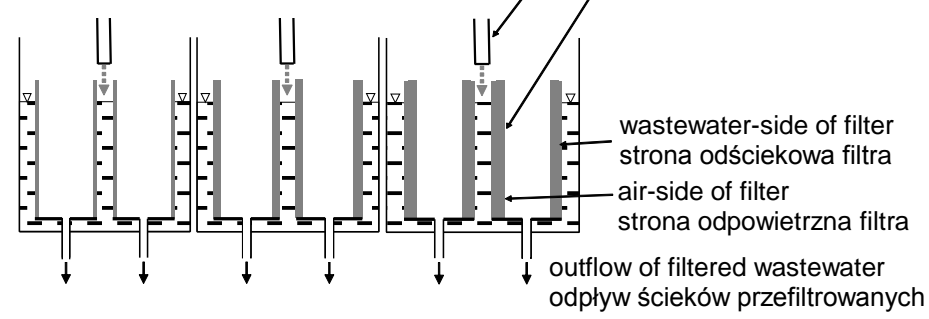

Fig. 1. Research reactors; a - plan view, b - cross section

Rys. 1. Reaktory badawcze; a - widok z góry, b - przekrój pionowy

all reactors on average, respectively). Concentrations of pollution indicators in wastewater before flow through the filters (present in the reactor) differed sometimes significantly from concentrations of pollution indicators flowing into the reactor (septic tank effluent), which was caused by the variability of wastewater flow into the reactor and the volume of wastewater remaining in the reactor after the previous doses.

Due to the successive rising of wastewater surface maximum and minimum level with time of experiment duration (partial clogging of filters and filter cake development) just after each dosage during several minutes the filtration was partly through the textile without biomass (no biological treatment). The above was taken into consideration and the treated (outflowing) wastewater samples were collected during the period of $3 \mathrm{~h}$, starting $10 \mathrm{~min}$ after the end of the dose.

The inflowing and outflowing wastewater was determined using the following indicators and parameters: suspended solids - using the dry-weight method; ammonium nitrogen, nitrites, nitrates and phosphorus - using the colorimetric method and biochemical oxygen demand - by respiration. To perform these measurements the following equipments were used: Merck spectrophotometer, pehameter CP-315, BOD 5 measurement set: OXI-TOP WTW. The measurements mentioned above were made in a physical-chemical laboratory located in the authors' institution.

The concentrations (mean values of the whole period of study) of main pollution indicators of investigated inflow wastewater were as follows: BOD $: R I-259 \pm 22.3 \mathrm{~g} / \mathrm{m}^{3}$, RII - $328 \pm 42.2 \mathrm{~g} / \mathrm{m}^{3}$, RIII $-313 \pm 29.6 \mathrm{~g} / \mathrm{m}^{3}$; COD: RI $-500 \pm 29.0 \mathrm{~g} / \mathrm{m}^{3}$, RII -557 $\pm 42.4 \mathrm{~g} / \mathrm{m}^{3}$, RIII $-539 \pm 30.8 \mathrm{~g} / \mathrm{m}^{3}$; ammonium nitrogen $\left(\mathrm{NH}_{4}-\mathrm{N}\right): \mathrm{RI}-108 \pm 5.3 \mathrm{~g} / \mathrm{m}^{3}$, RII $-121 \pm 6.1 \mathrm{~g} / \mathrm{m}^{3}$, RIII $-121 \pm 8.0 \mathrm{~g} / \mathrm{m}^{3}$; nitrites $\left(\mathrm{NO}_{2}-\mathrm{N}\right): \mathrm{RI}-0.43 \pm 0.14 \mathrm{~g} / \mathrm{m}^{3}$, RII $-0.43 \pm 0.14 \mathrm{~g} / \mathrm{m}^{3}$, RIII $-0.43 \pm 0.13 \mathrm{~g} / \mathrm{m}^{3}$; nitrates $\left(\mathrm{NO}_{3}-\mathrm{N}\right)$ : RI $-0.90 \pm 0.07 \mathrm{~g} / \mathrm{m}^{3}$, RII $-0.78 \pm 0.07 \mathrm{~g} / \mathrm{m}^{3}$, RIII $-0.79 \pm 0.08 \mathrm{~g} / \mathrm{m}^{3}$; phosphorus: RI $-18 \pm 1.2 \mathrm{~g} / \mathrm{m}^{3}$, RII -21 $\pm 3.0 \mathrm{~g} / \mathrm{m}^{3}$, RIII $-22 \pm 2.8 \mathrm{~g} / \mathrm{m}^{3}$; $\mathrm{pH}: 7.7-7.8$. The mentioned indicators were measured as filtered samples. 
Spychała, M., Łucyk, P. (2015). Effect of thickness of textile filter on organic compounds and nutrients removal efficiency at changeable wastewater surface level. Nauka Przyr. Technol., 9, 3, \#44. DOI : 10.17306/J .NPT.2015. 3.44

The research was carried out on three filter types of varying thickness. The thicknesses of filters were: $1.8 \mathrm{~mm}, 3.6 \mathrm{~mm}$ and $7.2 \mathrm{~mm}$ (two, four and eight layers of 0.9 mm thickness non-woven TS 20 textile, respectively). Reactor RI was equipped with four filters of thickness $1.8 \mathrm{~mm}$, reactor RII - with four filters of thickness $3.6 \mathrm{~mm}$ and reactor RIII - with four filters of thickness $7.2 \mathrm{~mm}$. The non-woven TS 20 geotextile properties were as follows: material $-100 \%$ polypropylene stabilised against UV radiation; statistics puncture resistance (CBR test) (EN ISO 12236) - $1500 \mathrm{~N}$; tensile strength (EN ISO 10319): MD, CD - $10 \mathrm{kN} / \mathrm{m}$ and $10 \mathrm{kN} / \mathrm{m}$, respectively; elongation at maximum load (EN ISO 10319): MD, CD - 90\% and 75\%, respectively; opening size $\mathrm{O}_{90}$ (EN ISO 12956) - $0.105 \mathrm{~mm}$, permeability vertical $2 \mathrm{kPa}$ (EN ISO 11058 ) (h= 50 $\mathrm{mm})-115 \mathrm{dm}^{3} / \mathrm{m}^{2} \cdot \mathrm{s}$; thickness at $2 \mathrm{kPa}$ (EN ISO 9863-1) - $0.9 \mathrm{~mm}$ and mass per unit area (EN ISO 9864) - $125 \mathrm{~g} / \mathrm{m}^{2}$.

The simulation of thicker filter layer by several thin layers enabling cross-sectional analyses performance was earlier mastered by Ren et al. (2010).

For better identification and explanation of thickness impact on principal facilities of wastewater treating textile filters the results obtained during the preliminary study for one-layer filters were utilised and discussed.

Samples to physical and chemical analyses were collected once a week (24 physical-chemical series of measurements). For dry mass examination, the textile samples of $2.8-11.4 \mathrm{~cm}^{2}$ surface area were cut out from a filter height of $0-10 \mathrm{~cm}$ and then pressed and washed. Next, the suspension was dried by heating at $105^{\circ} \mathrm{C}$ to a stable mass for identification of total solids content in filters.

Due to taking of filter layer samples (textile coupons) and despite covering the holes in filters with special stainless steel plates, some filters showed an enlarged flow capacity and had to be excluded from the data analysis at least until they recovered appropriate flow capacity. This in turn was responsible for the lack of some measurement data in figures.

Hydraulic capacity was calculated as the volume of wastewater, filtered within one day, divided by the lateral surface of the filter (the product of the average depth of the filter and its wetted-wastewater-side perimeter).

\section{Start-up period}

The start-up period in the case of treatment filtration is a time of achieving contaminant removal efficiency and hydraulic capacity stabilisation. Therefore the hydraulic and biological start-up periods can be distinguished. The hydraulic start-up period of filters took quite a long time, which was probably associated with sensitivity to various factors that were either external (pollutant concentration in septic tank effluent, temperature) or structural (heterogeneity of structure-porosity and textile pore size). It was observed that the start-up was much more intense when the inflow (STE) dosing and content was more stable. It was deemed that the hydraulic start-up period took about 2 to 3 months (decrease in hydraulic capacity for all filters from about $12-20 \mathrm{~cm}$ per day to about 5 to $10 \mathrm{~cm}$ per day, depending on the thickness of the filter). The biological start-up period for organic compounds removal was about 3 to 4 months and for nitrogen compounds - about 4 to 5 months. The arbitrarily chosen primary operation period (23.05-20.08) determined the mean values of obtained results presented in the paper. 
Spychała, M., Łucyk, P. (2015). Effect of thickness of textile filter on organic compounds and nutrients removal efficiency at changeable wastewater surface level. Nauka Przyr. Technol., 9, 3, \#44. DOI : 10.17306/J .NPT.2015. 3.44

\section{Dosing of septic tank effluent, hydraulic and contaminants loading}

After the start-up period, the filters were fed six times daily (every $4 \mathrm{~h}$ ) at a dose volume corresponding to the reactor volume attributable to one filter $\left(800 \mathrm{~cm}^{3}, 775 \mathrm{~cm}^{3}\right.$ and $738 \mathrm{~cm}^{3}$ for RI, RII and RIII on average, respectively) for the working height of wastewater level surface, i.e. 25-30 $\mathrm{cm}$ and surface area (the single filter circuit was about 30-32 cm).

As was observed for other working filters facilities (biomass structure, bacteria, protozoa and metazoan counts) the individual measurement values of removal efficiency for the same filter type (four replications) were highly differentiated due to several factors such as succession of biomass in time, changeability of inflowing wastewater quality, non-uniform structure of textiles and dissimilar conditions of wastewater mixing in the reactor during the dosing. However, in several aspects, statistically significant differences were observed for pairs of means (mean value of measurements in one series for four filters of the same type).

The function lines presented in the paper result not from modelling but from plotting the trend lines as best fitting to the measured data.

\section{Results and discussion}

\section{Hydraulic capacity of filters and total solids content}

The reactors operated at changeable wastewater surface levels. This was related to intermittent dosing and wastewater volume decrease due to the filtration at low reactor volume in relation to the filtration surface area. The minimum and maximum levels (average of last 15 weeks of experiment) were: 5.0 and $13.0 \mathrm{~cm}, 12.9$ and $25.9 \mathrm{~cm}, 25.4$ and $33.2 \mathrm{~cm}$ for RI, RII and RIII, respectively. Hydraulic capacity at the start of the experiment was between 12 and $20 \mathrm{~cm}$ per day (depending on the thickness of the filter). After the end of the start-up period hydraulic capacity was in the range of 5 to 10 $\mathrm{cm}$ per day. During the last 15 weeks of experiment the hydraulic capacity was between 5.8 and $8.1 \mathrm{~cm}$ per day (RI: $8.1 \mathrm{~cm}$ per day, RII: $6.4 \mathrm{~cm}$ per day and RIII: $5.8 \mathrm{~cm}$ per day, on average). The relation between working (covered by biomass) filter thickness and hydraulic capacity was shown in Figure 2 (the power function trend line with a high fitting coefficient of $\mathrm{R}^{2}=0.997$ can be used for this relation description).

The content of total solids in the cross-sectional profile of filter layer was differentiated. As was noted in other related experiments (Spychała and Starzyk, 2015) the highest content was observed in the first (wastewater-side) layer and commensurate to filter layer depth, the total solids content decreased. The lowest content was observed in the last (air-side layer). The whole (in all layers including filter cake on the first layer) total solids content was analysed as per the following contents: 8.16 (preliminary study), 13.45, 26.90 and $36.70 \mathrm{mg} / \mathrm{cm}^{2}$ in 1-, 2-, 4- and 8-layer filters, respectively. The relation between filter thickness (filter layers number) and total solids content was evident (Fig. 3) and could be described by the power function with a high fitting coefficient of $\mathrm{R}^{2}=0.997$. The values of accumulated matter in four layers of TS 20 geotextile (26.90 $\mathrm{mg} / \mathrm{cm}^{2}$ ) were comparable to those obtained from another experiment: $17.7 \mathrm{mg} / \mathrm{cm}^{2}$ of TS (Spychała and Nieć, 2013). 
Spychała, M., Łucyk, P. (2015). Effect of thickness of textile filter on organic compounds and nutrients removal efficiency at changeable wastewater surface level. Nauka Przyr. Technol., 9, 3, \#44. DOI : 10.17306/J .NPT.2015. 3.44

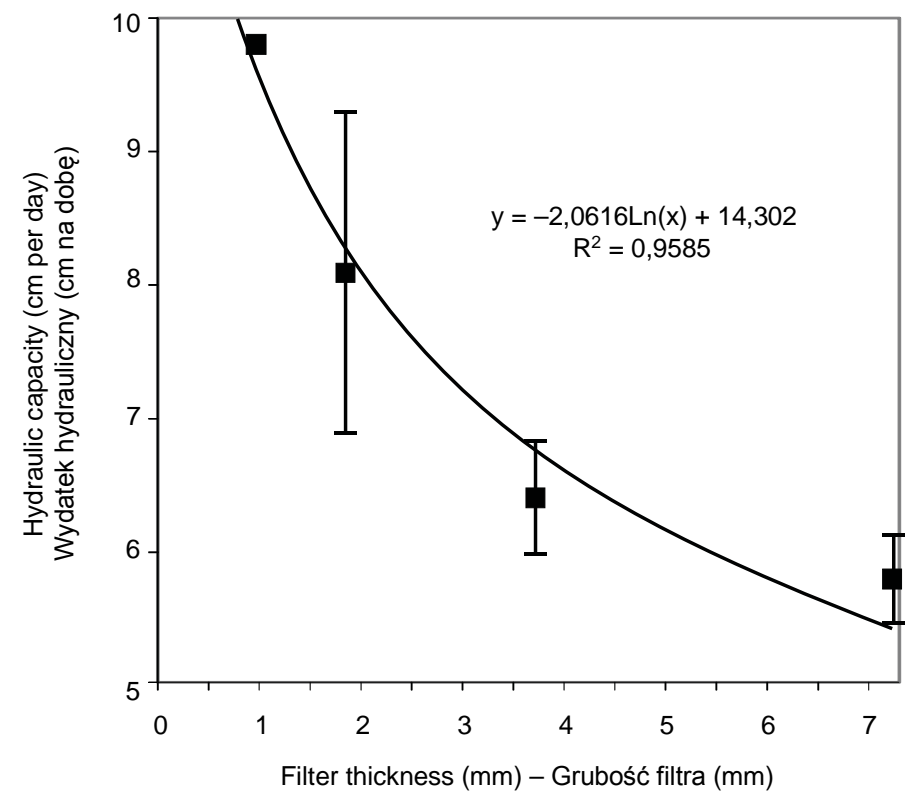

Fig. 2. Impact of filter thickness on hydraulic capacity Rys. 2. Wpływ grubości filtra na wydatek hydrauliczny

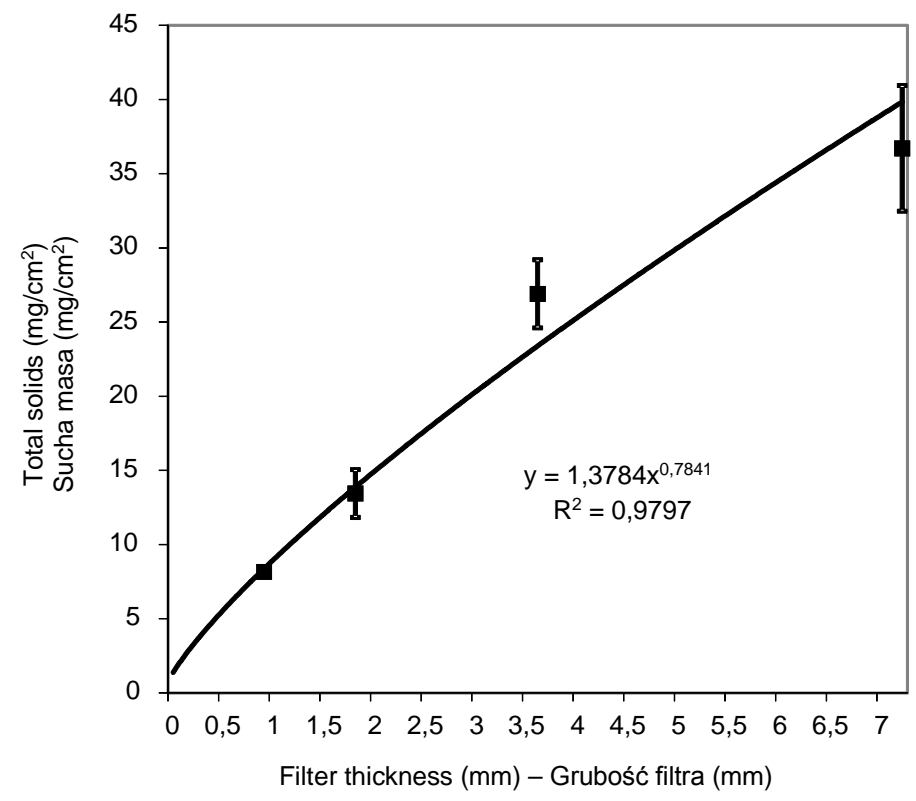

Fig. 3. Impact of filter thickness on total solids accumulation Rys. 3. Wpływ grubości filtra na akumulację suchej masy 
Spychała, M., Łucyk, P. (2015). Effect of thickness of textile filter on organic compounds and nutrients removal efficiency at changeable wastewater surface level. Nauka Przyr. Technol., 9, 3, \#44. DOI : 10.17306/J .NPT.2015. 3.44

\section{Removal efficiency}

\section{Organic compounds (expressed as COD and BOD5) removal}

The removal efficiency of organic compounds expressed as COD increased with the working time of filters, especially eight-layer filters (Fig. 4a). Some reactors at the end of the study (last month) demonstrated an efficiency of 70-85\%. The highest removal efficiency of COD (an average of four filters in 12-16 measurement series during last 3 months) was shown by eight-layer filters (reactor RIII): $64.3 \pm 1.84 \%(n=62)$, as presented in Figure 4b. Lower efficiency $(56.9 \pm 1.79 \%, n=58)$ was exhibited by four-layer filters. The lowest removal efficiency was observed for two-layer filters (48.3 $\pm 2.10 \%, \mathrm{n}=47)$.

a

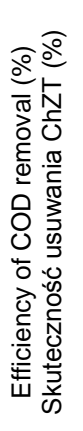

12345678910112131516718
Measurement series

Serie pomiarowe b

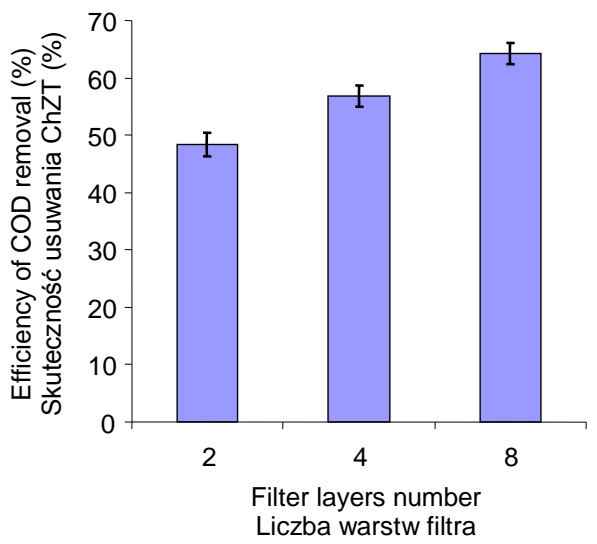

$\square 2$ layers $\quad \square 4$ layers $\quad \square 8$ layers
2 warstwy $\quad 4$ warstwy $\quad 8$ warstw

Fig. 4. Efficiency of COD removal; a - all measurements, b - average for filters thickness Rys. 4. Skuteczność usuwania ChZT; a - wszystkie pomiary, b - średnie dla grubości filtrów

Removal efficiency of organic pollutants expressed as $\mathrm{BOD}_{5}$ in the first several weeks after start-up period was slightly lower than the removal efficiency of COD (Fig. 5a). Finally at the end of the study, occasionally, $\mathrm{BOD}_{5}$ removal efficiency of particular filters was shown to be even higher than COD removal efficiency (87\%). Due to the low number of replications related to the small volume of wastewater outflow (very low wastewater surface level: minimum level $5.0 \mathrm{~cm}$ and maximum level $13.0 \mathrm{~cm}$ ), two-layer filters were excluded from the $\mathrm{BOD}_{5}$ removal efficiency analysis. The eight-layer filters were significantly more effective than four-layer filters (Fig. 5b). The efficiencies for four-layer and eight-layer filters were $63.3 \pm 3.58 \%(n=10)$ and $78.9 \pm 2.43 \%(n=$ 14), respectively (averages of two-three filters in six measurement series during last 3 months). 
Spychała, M., Łucyk, P. (2015). Effect of thickness of textile filter on organic compounds and nutrients removal efficiency at changeable wastewater surface level. Nauka Przyr. Technol., 9, 3, \#44. DOI : 10.17306/J .NPT.2015. 3.44

a

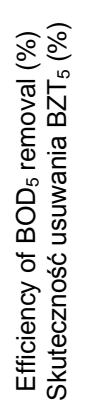

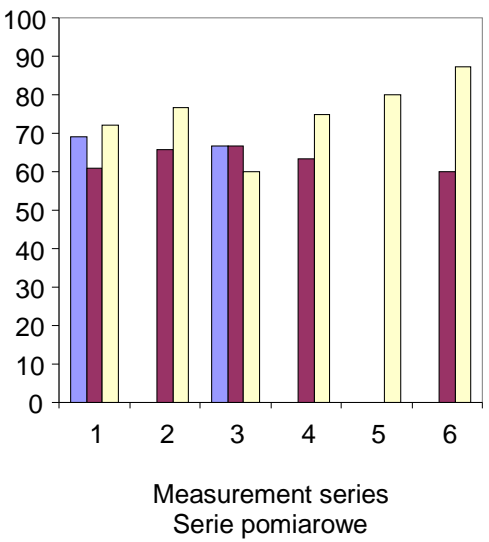

$\square 2$ layers $\quad \square 4$ layers $\quad \square 8$ layers
2 warstwy $\quad 4$ warstwy $\quad 8$ warstw b
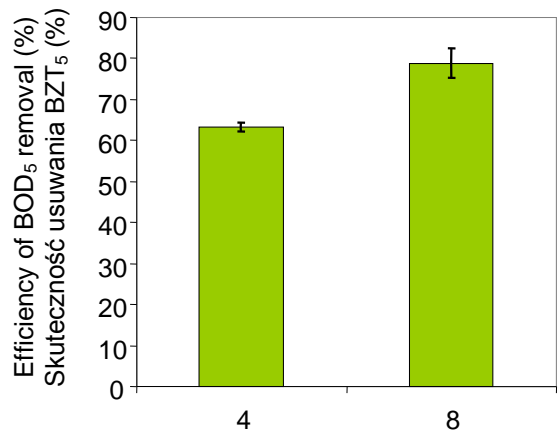

Filter layers number Liczba warstw filtra

Fig. 5. Efficiency of $\mathrm{BOD}_{5}$ removal; a - all measurements, $\mathrm{b}$ - average for filters thickness Rys. 5. Skuteczność usuwania BZT5; a - wszystkie pomiary, b - średnie dla grubości filtrów

\section{COD removal efficiency to filter capacity relation}

Analysis of the efficiency of organic compounds (expressed as COD) removal according to the hydraulic capacity of filters of varying thickness was performed in the period of the last 4 months of research (18 series of measurements).

From the analysis of Figures 6, 7 and 8 (single filters efficiencies) it can be concluded that the two-layer filters were the least effective in organic compounds removal (50-65\% at hydraulic capacity below $10.0 \mathrm{~cm}$ per day). These filters exhibited occasionally even higher efficiency (over 65\%) but at low hydraulic capacity only - below $5.0 \mathrm{~cm}$ per day. The four-layer filters were characterised by higher efficiency $(70-80 \%)$ compared to two-layer filters at a relatively wide range of hydraulic capacity - between $3.0 \mathrm{~cm}$ per day and $7.0 \mathrm{~cm}$ per day. The eight-layer filters exhibited the highest efficiency (80-85\%) at hydraulic capacity in a range similar to four-layer filters - between $3.0 \mathrm{~cm}$ per day and $6.0 \mathrm{~cm}$ per day. All filters, regardless of thickness, exhibited occasionally a low efficiency despite low hydraulic capacity. This phenomenon is difficult to explain - one possible reason could be the anaerobic conditions presence (despite low hydraulic capacity).

The impact of the layer thickness on the mean removal efficiency of COD was observed and it was found the relation was not linear. The trend line plotted based on logarithmic function, characteristic for first order kinetic substrate removal, was relatively highly correlated (coefficient of determination $\mathrm{R}^{2}=0.97$ ) with measurements (Fig. 9).

Organic loading rate (OLR) of biomass for the reactor with the highest removal efficiency (RIII) at the end of the study period was between $0.04 \mathrm{mg}$ BOD $_{5}$ per $1 \mathrm{mg}$ d.m. per day, for hydraulic capacity of about $5.0 \mathrm{~cm}$ per day and $0.07 \mathrm{mg}$ BOD $_{5}$ per $1 \mathrm{mg}$ d.m. 
Spychała, M., Łucyk, P. (2015). Effect of thickness of textile filter on organic compounds and nutrients removal efficiency at changeable wastewater surface level. Nauka Przyr. Technol., 9, 3, \#44. DOI : 10.17306/J .NPT.2015. 3.44

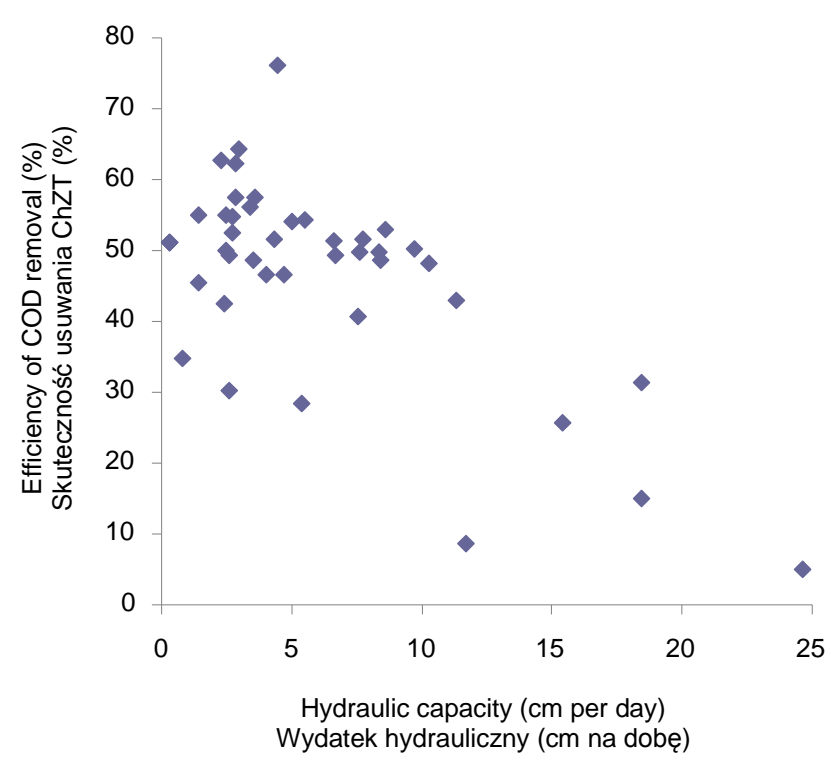

Fig. 6. Impact of hydraulic capacity on COD removal efficiency of two-layer filters

Rys. 6. Wpływ wydatku hydraulicznego na skuteczność usuwania ChZT przez filtry dwuwarstwowe

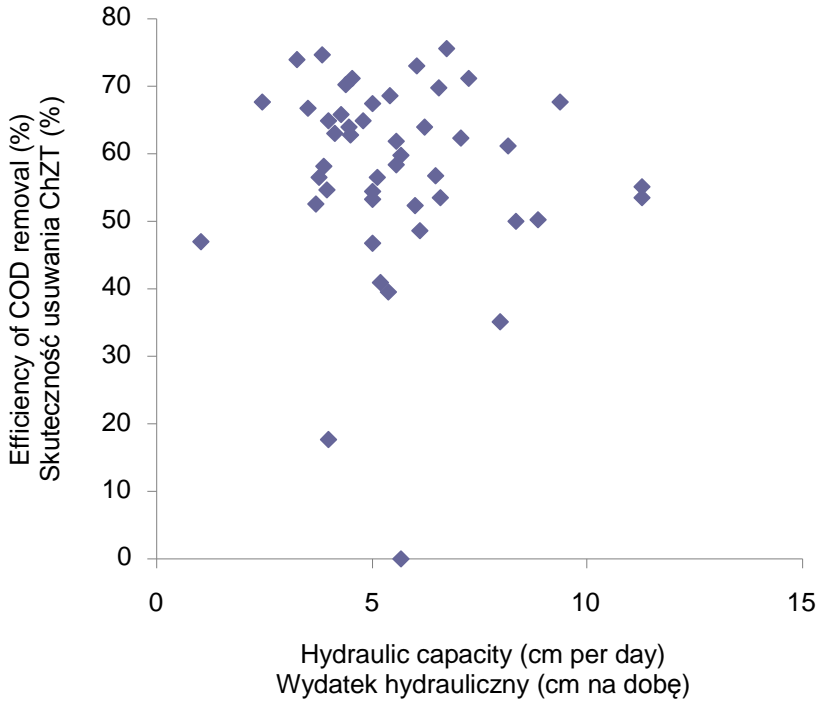

Fig. 7. Impact of hydraulic capacity on COD removal efficiency of four-layer filters

Rys. 7. Wpływ wydatku hydraulicznego na skuteczność usuwania ChZT przez filtry czterowarstwowe 
Spychała, M., Łucyk, P. (2015). Effect of thickness of textile filter on organic compounds and nutrients removal efficiency at changeable wastewater surface level. Nauka Przyr. Technol., 9, 3, \#44. DOI : 10.17306/J .NPT.2015. 3.44

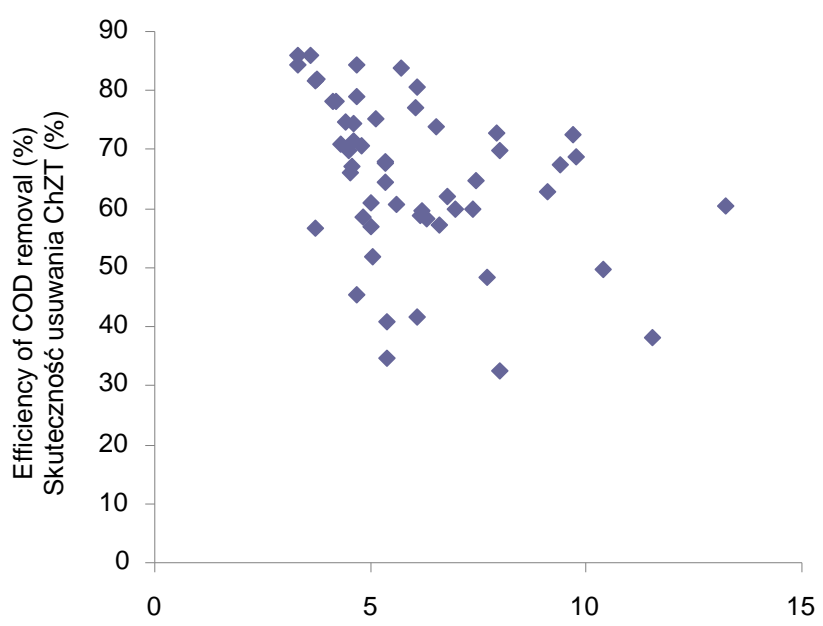

Hydraulic capacity (cm per day)

Wydatek hydrauliczny (cm na dobę)

Fig. 8. Impact of hydraulic capacity on COD removal efficiency of eight-layer filters

Rys. 8. Wpływ wydatku hydraulicznego na skuteczność usuwania ChZT przez filtry ośmiowarstwowe

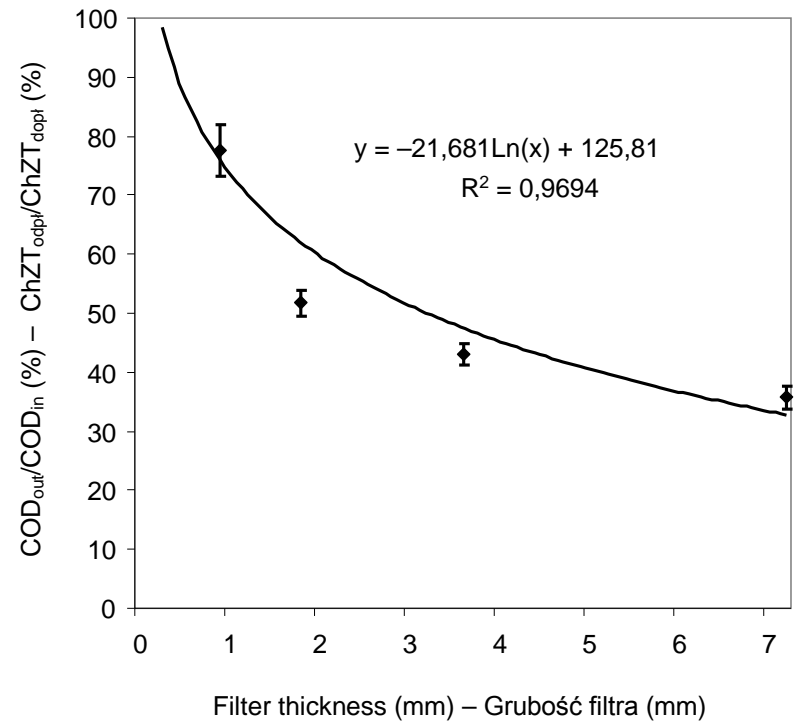

Fig. 9. Impact of filter thickness on remaining COD Rys. 9. Wpływ grubości filtra na ChZT w odpływie 
Spychała, M., Łucyk, P. (2015). Effect of thickness of textile filter on organic compounds and nutrients removal efficiency at changeable wastewater surface level. Nauka Przyr. Technol., 9, 3, \#44. DOI: 10.17306/J .NPT.2015. 3.44

per day, for hydraulic capacity of $10.0 \mathrm{~cm}$ per day and the amount of accumulated dry biomass of $36.7 \mathrm{mg} / \mathrm{cm}^{2}$. Such values - below $0.1-0.2 \mathrm{mg}$ BOD $_{5}$ per $1 \mathrm{mg} \mathrm{d} . \mathrm{m}$. per day are believed, by the operating guidelines for water resource recovery facilities and literature data (Imhoff and Novotny, 1989) to be conditions sufficient to achieve high organic compounds removal efficiency.

\section{Ammonium nitrogen and phosphorus removal efficiency}

The removal efficiency of ammonium nitrogen was for most of the research period very unstable. Most filters showed very large fluctuations - changes in the efficiency from the very small or even negative to several percent: 30-50\% (Fig. 10a). The thicker the filter layer - the higher the removal efficiency. The highest removal efficiency of ammonium nitrogen: $28.8 \pm 3.66 \%(n=34)$ was shown by eight-layer filters (Fig. 10b). Lower efficiency $-11.9 \pm 2.61 \%(n=38)$ was exhibited by four-layer filters, and the lowest and the most unstable in time - by two-layer filters $(7.7 \pm 3.78 \%, n=27)$. The highest efficiency (about 55\%), but in a very short period of time (just 2 weeks - two series of measurements) was shown by eight-layer filters. During this period the wastewater layer surface was the highest (about 20-30 cm), which could suggest the beneficial effect of air-side surface and thin wastewater layer on the oxidation of ammonium nitrogen.

a

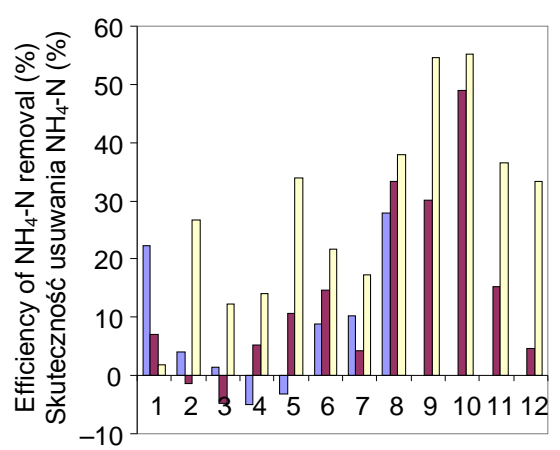

Measurement series

Serie pomiarowe b

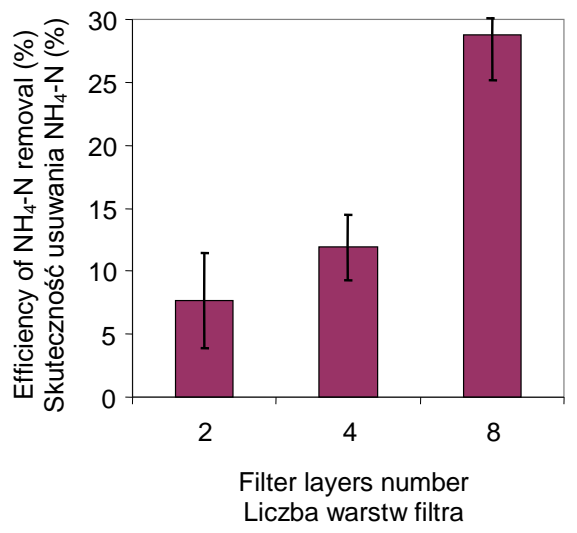

$\square 2$ layers $\quad \square$ 4 layers $\quad \square 8$ layers
2 warstwy $\quad 4$ warstwy $\quad 8$ warstw

Fig. 10. Efficiency of ammonium nitrogen removal; a - all measurements, $b$ - average for filters thickness

Rys. 10. Skuteczność usuwania azotu amonowego; a - wszystkie pomiary, b - średnie dla grubości filtrów

The comparable ammonium nitrogen removal efficiency and nitrite and nitrate concentrations were observed during a previous study on similar types of filters but made of different geotextile type (Spychała et al., 2013). The ammonium nitrogen removal effi- 
Spychała, M., Łucyk, P. (2015). Effect of thickness of textile filter on organic compounds and nutrients removal efficiency at changeable wastewater surface level. Nauka Przyr. Technol., 9, 3, \#44. DOI : 10.17306/J .NPT.2015. 3.44

ciency in that study was for the last two months $40 \%$ and for the last month $56 \%$ on average, however the ammonium nitrogen concentration in inflowing wastewater (STE) was much lower (excluding the last 3 weeks) - about $20 \mathrm{~g} / \mathrm{m}^{3}$ on average only.

The nitrite-nitrogen and nitrate-nitrogen concentrations in the Spychała et al. (2013) study in inflowing wastewater $\left(\mathrm{NO}_{2}-\mathrm{N}\right.$ : $\left.0.081 \pm 0.012 \mathrm{~g} / \mathrm{m}^{3}, \mathrm{NO}_{3}-\mathrm{N}: 0.99 \pm 0.09 \mathrm{~g} / \mathrm{m}^{3}\right)$ were comparable to those observed during this study $\left(\mathrm{NO}_{2}-\mathrm{N}\right.$ : below $0.5 \mathrm{~g} / \mathrm{m}^{3}$ and $\mathrm{NO}_{3}-\mathrm{N}$ : below $1.0 \mathrm{~g} / \mathrm{m}^{3}$ ).

In this study no changes (no statistical difference between means) between nitrite concentration in inflowing and outflowing wastewater were observed $\left(0.43 \mathrm{~g} / \mathrm{m}^{3}\right.$ and $0.44 \mathrm{~g} / \mathrm{m}^{3}$ on average, respectively). The same phenomenon was observed for nitrate concentrations: $0.82 \mathrm{~g} / \mathrm{m}^{3}$ and $0.82 \mathrm{~g} / \mathrm{m}^{3}$ on average, respectively. However relatively high total nitrogen removal efficiency was observed: $37.76 \pm 6.15 \%$. However Furukawa et al. (2003) observed higher total nitrogen removal efficiency (about 60\%) in reactor with non-woven carrier.

Conditions conducive to ammonium nitrogen oxidation were also confirmed by ammonium oxidizing bacteria identification (Spychała and Starzyk, 2015), using a Nitri-VIT $^{\circledR}$ gene probe technology set that contains a mixture of oligonucleotide DNA. These DNA probes are complementary to specific 16S rRNA sequences of the common ammonium oxidizing bacteria, as reported by Woznica et al. (2010). In this context, DO concentration was sufficient for ammonium nitrogen oxidation both in this and in the Spychała et al. (2013) study - about $0.5-1.0 \mathrm{~g} / \mathrm{m}^{3}$ (in air-side layers of filter) and about $6.0 \mathrm{~g} / \mathrm{m}^{3}$ (in outflowing wastewater), respectively.

Neither nitrites nor nitrates were observed during this study (Spychała and Starzyk, 2015), however these kinds of bacteria were observed during a study made by Spychała et al. (2013) on TS50 geotextile filters - the NOB number from $1.9 \times 10^{3}$ to $1.1 \times 10^{5}$ $\mathrm{CFU} / \mathrm{cm}^{2}$.

The low nitrites and nitrates concentrations in the outflowing wastewater could be related to inhibition under low DO concentration (Jia et al., 2012) and shortened nitrogen oxidizing pathway (e.g. by anammox process). However another scenario could be also realized - a simultaneous nitrification-denitrification process.

The Kjeldahl and total nitrogen removal of about $19 \%$ and $27 \%$, respectively (the latter indicator was occasionally higher in effluent than in influent) in the Spychała et al. (2013) study at low concentrations of nitrites and nitrates in effluent would seem to be some confirmation of denitrification (probably simultaneous with nitrification) or anammox process.

The terms of nitrogen compounds related processes were described and commented in details in Spychała and Starzyk (2015) paper.

The nitrogen compounds removal in TFWT can be explained by the occurrence of the anammox process but this thesis requires verification. However, there are some reports related to the occurrence of this process under similar conditions. Fuji et al. (2002) found the removal of ammonium and nitrite under anoxic conditions in reactor which was equipped with non-woven carrier. Recent research has shown that it is possible to obtain this process under low temperature conditions (Dosta et al., 2007) and low ammonium concentration in wastewater inflow into the reactor (Pathak et al., 2007). A recent study (Liu et al., 2008) has shown a very interesting phenomenon. Anammox process has been believed to be anaerobic. Indeed the above process requires anaerobic 
Spychała, M., Łucyk, P. (2015). Effect of thickness of textile filter on organic compounds and nutrients removal efficiency at changeable wastewater surface level. Nauka Przyr. Technol., 9, 3, \#44. DOI: 10.17306/J .NPT.2015. 3.44

conditions but the absence of oxygen in a microenvironment is sufficient although aerobic conditions can occur (about $1-2 \mathrm{~g} \mathrm{O}_{2}$ per $1 \mathrm{~m}^{3}$ even) in the bulk liquid (solution) of the reactor. Liu et al. (2008) noted that two strains of nitrifying bacteria (similar to $\mathrm{Ni}$ trosomonas eutropha) exhibited the possibility of living for relatively long periods in autotrophic anaerobic conditions, protecting in this manner anammox bacteria (Planctomycetales) from the influence of inhibiting oxygen.

The relationship of ammonium nitrogen removal efficiency to the thickness of filters was analysed. As for COD removal, in the case of ammonium nitrogen removal, it was difficult to observe any clear relation, apart from the fact that the two-layer filters showed a slightly higher performance at lower hydraulic capacity (2-10 cm per day).

The removal of total nitrogen in this study could suggest that denitrification occurred at least in some regions of the filter. As mentioned in the introduction chapter the aim of the study was to verify the occurrence of conditions for high oxygen demand processes (ammonium oxidation) rather than to recognize complete total nitrogen removal. It is known fact that due to the impossibility of DO concentration control it is difficult to maintain a stable total nitrogen removal process in the one attached biomass reactor (as in case of conventional one stage trickling filters). The filters should be used as a part of an onsite wastewater treatment plant rather than as self-reliant reactors. In aim to achieve a stable denitrification the filters should be coupled with additional device and should operate under more complex technological conditions. Further studies should be carried out to verify effective total nitrogen removal in the reactor with separated anaerobic region, treated wastewater recirculation or other modifications or configurations.

The mean value of total phosphorus $\left(\mathrm{P}_{\text {tot }}\right)$ removal for all reactors increased over time of the experiment from about $25 \%$ after five months from the start-up period finish to over $40 \%$ (for eight-layer filters) at the end of the experiment (Fig. 11a). The highest removal efficiency of $\mathrm{P}_{\text {tot }}-40.3 \pm 2.52 \%(\mathrm{n}=23)$ was exhibited by eight-layer filters (reactor RIII). Lower efficiency $-32.4 \pm 3.38 \%(n=18)$ was shown by four-layer filters (RII). The least stable in time and the lowest removal efficiency was presented by two-layer filters (RI): $21.4 \pm 3.27 \%(n=12)$. The results of the impact of filter thickness on the total phosphorus removal were presented in Figure 11b.

The positive effect of biomass concentration on removal efficiency can be related not only to mass strictly but also to their effective surface area, especially when this biomass occurs in the form of bio-consortia. Other studies (opus in progressu) showed that mean and range of biomass consortia dimension within the non-woven textile inert space (about $60 \mu \mathrm{m}$ on average) was similar to activated sludge flocs (63-126 $\mu \mathrm{m}$; Peng et al., 2012). The biomass consortia of about several hundred micrometres (common size of activated sludge flocs) are in a relatively similar range - from 40 to $350 \mathrm{~m}^{2} / \mathrm{g}$ of specific surface, e.g. Smith and Coackley (1983) reported 40-140 m²/g, Andreadakis (1993) - from 100 to $200 \mathrm{~m}^{2} / \mathrm{g}$ and Bishop et al. (1995) noted the widest range: 80-350 $\mathrm{m}^{2} / \mathrm{g}$ dry solids.

Several studies were conducted that showed a low DO concentration can cause some advantages in wastewater treatment. Guo et al. (2009) found that in polyurethane foam cube biofilm reactors higher pollutants removal efficiency can be achieved maintaining lower DO concentration. At lower DO concentration the higher resistance to shock loadings and less time demand for start-up were observed, compared to a system with higher DO concentration. 
Spychała, M., Łucyk, P. (2015). Effect of thickness of textile filter on organic compounds and nutrients removal efficiency at changeable wastewater surface level. Nauka Przyr. Technol., 9, 3, \#44. DOI : 10.17306/J .NPT.2015. 3.44

a

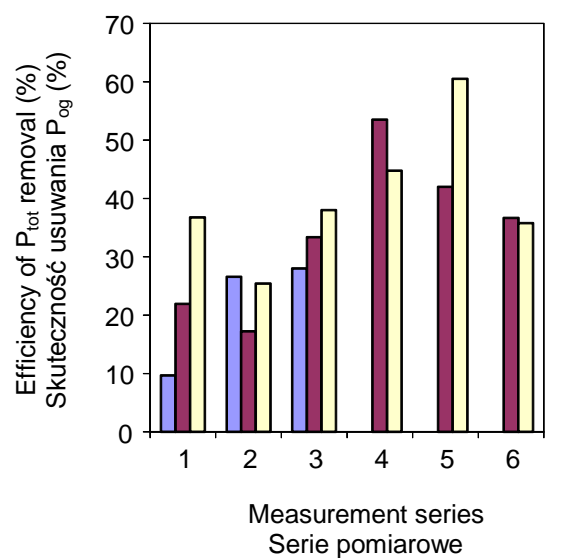

Serie pomiarowe b

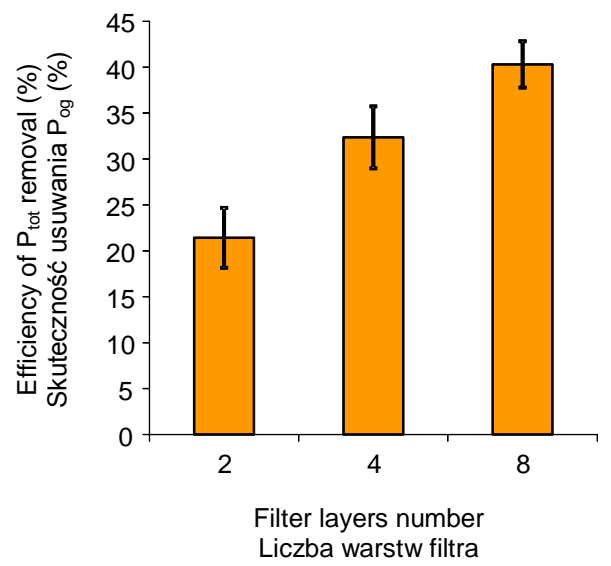

$\square 2$ layers $\quad \square$ 4 layers $\quad \square 8$ layers
2 warstwy $\quad 4$ warstwy $\quad 8$ warstw

Fig. 11. Efficiency of total phosphorus removal; a - all measurements, b - average for filters thickness

Rys. 11. Skuteczność usuwania fosforu ogólnego; a - wszystkie pomiary, b - średnie dla grubości filtrów

The pollution indicators (except Escherichia coli index) investigated in this study are accorded to indicators defining the Wastewater Polishing Index (WWPI) - the "weighted average" of the following six parameters: suspended solids (SS), biochemical oxygen demand $\left(\mathrm{BOD}_{5}\right)$, chemical oxygen demand (COD), ammonium nitrogen, total phosphorous (P) and Escherichia coli (E. coli) index. The WWPI enables a rapid comparison of wastewater quality (Mudiya, 2012).

Minimum hydraulic capacity and maximum COD removal efficiency can be related to the establishment of maximum filter cake mass. Under conditions of vertical orientation of filtering layer the excess mass is removed due to the gravity force (sedimentation). Similar phenomenon was observed for filter cake formed on the vertically oriented membrane (Chomiak et al., 2014b).

The eight-layer filters used for the process were the most effective - demonstrating a high and stable removal efficiency of dissolved compounds (COD, BOD $5, \mathrm{P}_{\text {tot }}$ ) at relatively stable hydraulic capacity.

Total suspended solids removal efficiencies proved to be eminently variable and unsuspected tendency was observed: the thinner the filter layer - the lower the total suspended solids concentration in the effluent. The increased concentration of the total suspended solids in the effluent from the filters might be related to excess biomass of filter layer detachment and outflow from the reactors (no secondary clarifier was used in the study). For all filters, the removal efficiency of suspended solids fitted generally within the range $70-90 \%$. 
Spychała, M., Łucyk, P. (2015). Effect of thickness of textile filter on organic compounds and nutrients removal efficiency at changeable wastewater surface level. Nauka Przyr. Technol., 9, 3, \#44. DOI: 10.17306/J .NPT.2015. 3.44

\section{Hydraulic retention time}

The hydraulic retention time (HRT) was calculated based on filter cake thickness, uncovered by biomass textile porosity, wetted biomass volume and hydraulic capacity. The calculated HRT was low for two-layer filters $-0.45 \mathrm{~h}$ only. The highest calculated HRT was for eight-layer filter - about $3.3 \mathrm{~h}$, and the intermediate - for four-layer filters - about $1 \mathrm{~h}$.

It is worth to note that HRT values are calculated and based on mean hydraulic capacity and that local hydraulic conditions may significantly differ from mean values. Comparing these results with the literature only four- and eight-layer filter hydraulic retention times can be treated as sufficient for biological treatment. However there are some results showing that a relatively high removal of COD can be achieved at extremely short HRT in specific conditions (Rezaei et al., 2012). Rezaei et al. (2012) investigated the novel airlift reactor using glucose and aniline as a carbon source (inoculated with fresh activated sludge from municipal water resource recovery facility) and operated at $4 \mathrm{~h}$ per cycle. The reactors reached COD removal efficiency over $97 \%$ for glucose and $94.5 \%$ for aniline as a source of carbon at organic loading (COD) rates in a range from $0.6 \mathrm{~kg} / \mathrm{m}^{3}$ per day to $5.4 \mathrm{~kg} / \mathrm{m}^{3}$ per day. These authors found that over $80 \%$ of COD was utilised during the first $30 \mathrm{~min}$ of cycle.

The high removal of nitrogen compounds with utilization of anammox process was noted by Tsushima et al. (2007) for biofilm reactors. The research was made at hydraulic retention time ( $1 \mathrm{~h}$ and $4 \mathrm{~h}$ ) similar to the obtained in this study.

Other relatively short HRTs (about $4 \mathrm{~h}$ ) mentioned in the literature are related mostly to submerged membrane bioreactor (Jadhao and Dawande, 2013; Visvanathan et al., 2000). These reactors can be operated at short HRT thanks to the presence of membrane as a device for activated sludge collection. Jadhao and Dawande (2013) observed high efficiencies of pollutants removal in submerged membrane bioreactor (MBR) for longer but comparable (especially for eight layers textile filters) HRT - the shortest scenario with $4 \mathrm{~h}$ HRT. It should be noted that MBR works at relatively high dissolved oxygen concentrations. The shortest HRT mentioned in the literature, not requiring clogging preventing aeration, are in the range of 2-3 h (Visvanathan and Abeynayaka, 2012; Visvanathan et al., 2000). On the other hand, there were noted longer hydraulic retention times preferred for attached biomass reactors (e.g. moving bed biological reactors) - 5 h (Andreottola et al., 2000).

The possibility of organic compounds and ammonium nitrogen removal as identified during this study HRT (3-4 h) was confirmed theoretically by preliminary biochemical modelling (Spychała and Starzyk, 2015).

\section{Conclusions}

The positive effect of biomass concentration on the removal efficiency and the relation between filter thickness and the hydraulic capacity was observed.

The highest treatment efficiency was obtained for the filters with the greatest thickness for all the studied indicators of pollution. The observed TSS concentrations in wastewater outflow lead the authors to conclude that for the technical scale application, 
Spychała, M., Łucyk, P. (2015). Effect of thickness of textile filter on organic compounds and nutrients removal efficiency at changeable wastewater surface level. Nauka Przyr. Technol., 9, 3, \#44. DOI : 10.17306/J .NPT.2015. 3.44

the TFWT should be equipped with a secondary settler. The thicker the filter layer, the higher the removal efficiency.

The eight-layer filters proved to be the most effective - demonstrating high and relatively stable removal efficiency and hydraulic capacity. The highest calculated HRT was for eight-layer filter (about $3.3 \mathrm{~h}$ ).

The results showed that there is a relation between filter thickness and organic compounds removal efficiency. To achieve efficiency at about $80-85 \%$ for COD and $\mathrm{BOD}_{5}$ the eight-layer filter is recommended. About $2-5 \mathrm{~m}^{2}$ of filtering surface of this filter thickness is required for one PE and cleaning of filters (aimed to filter cake removal) is not needed up to at least 2 years. This type of filter and reactor is promising correspondingly to practical implementation due to the relatively high organic compounds removal efficiency at low costs and due to the easy controlling.

As the TFWT are a type of attached bioreactor containing only filters as biomass supporting material (similar to other bioreactor types, e.g. trickling filters), additional devices are needed for excess biomass removal (secondary settler).

\section{References}

Alimahmoodi, M., Yerushalmi, L., Mulligan, C. N. (2012). Development of biofilm on geotextile in a new multi-zone wastewater treatment system for simultaneous removal of COD, nitrogen and phosphorus. Bioresour. Technol., 107, 78-86.

Andreadakis, A. D. (1993). Physical and chemical properties of activated sludge floc. Water Res., 27, 12, 1707-1714.

Andreottola, G., Foladori, P., Ragazzi, M. (2000). Upgrading of a small wastewater treatment plant in a cold climate region using a moving bed biofilm reactor (MBBR) system. Water Sci. Technol., 41, 1, 177-185.

Bishop, P. L., Zhang, T. C., Fu, Y.-C. (1995). Effects of biofilm structure, microbial distributions and mass transport on biodegradation processes. Water Sci. Technol., 31, 1, 143-152.

Chomiak, A., Mimoso, J., Koetzsch, S., Sinnet, B., Pronk, W., Derlon, N., Morgenroth, E. (2014a). Biofilm formation and permeate quality improvement in Gravity Driven Membrane ultrafiltration. Water Sci. Technol. Water Supply, 14, 2, 274-282.

Chomiak, A., Sinnet, B., Derlon, N., Morgenroth, E. (2014b). Inorganic particles increase biofilm heterogeneity and enhance permeate flux. Water Res., 64, 177-186.

Del Pozo, R., Diez, V. (2005). Integrated anaerobic-aerobic fixed film reactor for slaughterhouse wastewater treatment. Water Res., 39, 6, 1114-1122.

Dosta, J., Fernández, I., Vázquez-Padín, J. R., Mosquera-Corral, A., Campos, J. L., MataÁlvarez, J., Méndez, R. (2007). Short- and long-term effects of temperature on the anammox process. J. Hazard. Mater., 154, 688-693.

Fuji, T., Sugino, H., Joseph, D. R., Furukawa, K. (2002). Characterization of the microbial community in an anaerobic ammonium-oxidizing biofilm cultured on a nonwoven biomass carrier. J. Biosci. Bioeng., 94, 5, 412-418.

Furukawa, K., Rouse, J. D., Yoshida, N., Hatanaka, H. (2003). Mass cultivation of anaerobic ammonium-oxidizing sludge using a novel nonwoven biomass carrier. J. Chem. Eng. Jpn., 36, 10, 1163-1169.

Gullicks, H., Hasan, H., Das, D., Moretti, C., Hung, Y.-T. (2011). Biofilm fixed film systems. Water (Basel), 3, 843-868. 
Spychała, M., Łucyk, P. (2015). Effect of thickness of textile filter on organic compounds and nutrients removal efficiency at changeable wastewater surface level. Nauka Przyr. Technol., 9, 3, \#44. DOI : 10.17306/J .NPT.2015. 3.44

Guo, J., Ma, F., Chang, C. C. (2009). Start-Up of a two-stage bioaugmented anoxic-oxic (a/o) biofilm process treating petrochemical wastewater under different do concentrations. Bioresour. Technol., 100, 3483-3488.

Guo, H., Zhou, J., Su, J., Zhang, Z. (2005). Integration of nitrification and denitrification in air lift bioreactor. Biochem. Eng. J., 23, 57-62.

Hibiya, K., Nagai, J., Tsuneda, S., Hirata, A. (2004). Simple prediction of oxygen penetration depth in biofilms for wastewater treatment. Biochem. Eng. J., 19, 61-68.

Imhoff, K., Novotny, V. (1989). Karl Imhoff's handbook of urban drainage and wastewater disposal. New York: Wiley.

Jadhao, R. K., Dawande, S. D. (2013). Effect of hydraulic retention time and sludge retention time on membrane bioreactor: performance in summer season. Int. J. Chem. Phys. Sci., 2, 2, $1-18$.

Jia, L., Guo, J., Fang, F., Chen, Y., Zhang, Q. (2012). Effect of organic carbon on nitrogen conversion and microbial communities in the completely autotrophic nitrogen removal process. Environ. Technol., 33, 10, 1141-1149.

Jin, R.-C., Yang, G.-F., Yu, J.-J., Zheng, P. (2012). The inhibition of the Anammox process: a review. Chem. Eng. J., 197, 67-79.

Korkut, E. N., Martin, J. P., Yaman, C. (2006). Wastewater treatment with biomass attached to porous geotextile baffles. J. Environ. Eng., 132, 2, 284-288.

Li, Z. H., Yang, K., Yang, X. J., Li, L. (2010). Treatment of municipal wastewater using a contact oxidation filtration separation integrated bioreactor. J. Environ. Manage., 91, 5, 1237-1242.

Liu, S., Yang, F., Xue, Y., Gong, Z., Chen, H., Wang, T., Su, Z. (2008). Evaluation of oxygen adaptation and identification of functional bacteria composition for anammox consortium in non-woven biological rotating contactor. Bioresour. Technol., 99, 8273-8279.

Luciano, A., Viotti, P., Mancini, G., Torretta, V. (2012). An integrated wastewater treatment system using a BAS reactor with biomass attached to tubular supports. J. Environ. Manage., 113, 51-60.

Mudiya, B. N. (2012). Development of wastewater quality index for disposal in to environmental sink - "Inland Surface Waters". Int. J. Comput. Appl., 5, 9-12.

Nicolella, C., van Loosdrecht, M. C. M., Heijnen, S. J. (2000a). Particle-based biofilm reactor technology. Trends Biotechnol., 18, 7, 312-320.

Nicolella, C., van Loosdrecht, M. C. M., Heijnen, J. J. (2000b). Wastewater treatment with particulate biofilm reactors. J. Biotechnol., 80, 1, 1-33.

Pathak, B. K., Kazama, F., Saiki, Y., Sumino, T. (2007). Presence and activity of anammox and denitrification process in low ammonium-fed bioreactors. Bioresour. Technol., 98, 11, 22012206.

Peng, G., Ye, F., Li, Y. (2012). Investigation of extracellular polymer substances (EPS) and physicochemical properties of activated sludge from different (municipal and industrial) wastewater treatment plants. Environ. Technol., 33, 8, 857-863.

Ren, X., Shon, H. K., Jang, N., Lee, Y. G., Bae, M., Lee, J., Cho, K., Kim, I. S. (2010). Novel membrane bioreactor (MBR) coupled with a nonwoven fabric filter for household wastewater treatment. Water Res., 44, 3, 751-760.

Rezaei, L. S., Ayati, B., Ganjidoust, H. (2012). Cultivation of aerobic granules in a novel configuration of sequencing batch airlift reactor. Environ. Technol., 33, 20, 2273-2280.

Smith, P. G., Coackley, P. A. (1983). A method for determining specific surface area of activated sludge by dye adsorption. Water Res., 17, 5, 595-598.

Spychała, M., Błażejewski, R., Nawrot, T. (2013). Performance of innovative textile biofilters for domestic wastewater treatment. Environ. Technol., 34, 2, 157-163.

Spychała, M., Nieć, J. (2013). Impact of septic tank sludge on filter permeability. Environ. Prot. Eng., 39, 2, 77-89. 
Spychała, M., Łucyk, P. (2015). Effect of thickness of textile filter on organic compounds and nutrients removal efficiency at changeable wastewater surface level. Nauka Przyr. Technol., 9, 3, \#44. DOI : 10.17306/J .NPT.2015. 3.44

Spychała, M., Starzyk, J. (2015). Bacteria in non-woven textile filters for domestic wastewater treatment. Environ. Technol., 36, 8, 937-945.

Tsushima, I., Ogasawara, Y., Kindaichi, T., Satoh, H., Okabe, S. (2007). Development of highrate ammonium-oxidizing (anammox) biofilm reactors. Water Res., 41, 8, 1623-1634.

Vázquez-Padín, J., Fernández, I., Figueroa, M., Mosquera-Corral, A., Campos, J. L., Méndez, R. (2009). Applications of Anammox based processes to treat anaerobic digester supernatant at room temperature. Bioresour. Technol., 100, 2988-2994.

Visvanathan, C., Abeynayaka, A. (2012). Developments and future potentials of anaerobic membrane bioreactors (AnMBRs). Membrane Water Treat., 3, 1, 1-23.

Visvanathan, C., Aimand, R. B., Parameshwaran, K. (2000). Membrane separation bioreactor for wastewater treatment. Crit. Rev. Environ. Sci. Technol., 30, 1, 1-48.

Walters, E., Hille, A., He, M., Ochmann, C., Horn, H. (2009). Simultaneous nitrification/denitrification in a biofilm airlift suspension (BAS) reactor with biodegradable carrier material. Water Res., 43, 18, 4461-4468.

Wang, X., Kim, K., Lee, C., Kim, J. (2008). Prediction of air filter efficiency and pressure drop in air filtration media using a stochastic simulation. Fiber. Polym., 9, 1, 34-38.

Woznica, A., Nowak, A., Beimfohr, C., Karczewski, J., Bernas, T. (2010). Monitoring structure and activity of nitrifying bacterial biofilm in an automatic biodetector of water toxicity. Chemosphere, 78, 1121-1128.

Zhang, X., Zhou, J., Guo, H., Qu, Y., Liu, G., Zhao, L. (2007). Nitrogen removal performance in a novel combined biofilm reactor. Process Biochem., 42, 620-626.

\section{WPŁYW GRUBOŚCI FILTRA WŁÓKNINOWEGO NA SKUTECZNOŚĆ USUWANIA ZWIĄZKÓW ORGANICZNYCH I BIOGENNYCH W WARUNKACH ZMIENNEGO POZIOMU ŚCIEKÓW}

Streszczenie. Celem badań było rozpoznanie wpływu grubości nowatorskich filtrów (filtry włókninowe do oczyszczania ścieków) na skuteczność usuwania związków rozpuszczonych oraz na związane z tym warunki technologiczne: stężenie biomasy, wydajność hydrauliczną i czas retencji. Badania prowadzono na ściekach odpływających z osadnika gnilnego. Odpływ z osadnika gnilnego był filtrowany przy zmiennym poziomie ścieków - pomiędzy $7 \mathrm{~cm}$ a $20 \mathrm{~cm}$ wysokości filtra pod ciśnieniem hydrostatycznym. Eksperyment był wykonany z użyciem filtrów o grubości 1,8 $\mathrm{mm}, 3,6 \mathrm{~mm}$ i 7,2 mm. Wykazano tym większą skuteczność usuwania związków rozpuszczonych, im większa była grubość filtrów. Filtry o najmniejszej grubości wykazały największy wydatek hydrauliczny i największą skuteczność usuwania zawiesiny ogólnej. Obliczony średni czas retencji wynosił odpowiednio: 0,5 h, 1,1 h i 3,3 h dla dwu-, cztero- i ośmiowarstwowych filtrów.

Słowa kluczowe: azot amonowy, rozpuszczone związki organiczne, włóknina, filtr włókninowy do oczyszczania ścieków, oczyszczanie ścieków

Corresponding address - Adres do korespondencji:

Marcin Spychała, Katedra Inżynierii Wodnej i Sanitarnej, Uniwersytet Przyrodniczy w Poznaniu, ul. Piątkowska 94, 60-649 Poznań, Poland, e-mail: marsp@up.poznan.pl 
Spychała, M., Łucyk, P. (2015). Effect of thickness of textile filter on organic compounds and nutrients removal efficiency at changeable wastewater surface level. Nauka Przyr. Technol., 9, 3, \#44. DOI : 10.17306/J .NPT.2015. 3.44

Accepted for publication - Zaakceptowano do opublikowania:

9.04.2015

For citation - Do cytowania:

Spychała, M., Eucyk, P. (2015). Effect of thickness of textile filter on organic compounds and nutrients removal efficiency at changeable wastewater surface level. Nauka Przyr. Technol., 9, 3, \#44. DOI: 10.17306/J.NPT.2015.3.44 